\title{
LETTER
}

\section{REE/Fe variations in hydrothermal sediments: Implications for the REE content of seawater}

\author{
Annette M. Olivarez and Robert M. OWen* \\ Oceanography Program, Department of Geological Sciences, University of Michigan, Ann Arbor, MI 48109-1063, U.S.A.
}

(Received November 22, 1988; accepled in revised form February 8, 1989)

\begin{abstract}
Seafloor hydrothermal vent solutions exhibit rare earth element (REE) enrichments ranging between one to three orders of magnitude greater than average seawater. To assess the impact of these hydrothermal inputs on ocean chemistry, we have examined the behavior of REEs for hydrothermal sediments collected adjacent to two Pacific spreading ridge sites: the East Pacific Rise at $19^{\circ} \mathrm{S}$, and the Southern Juan de Fuca Ridge at $45^{\circ} \mathrm{N}$. In general, the REE/Fe ratios for both proximal and distal hydrothermal sediments are greater than vent solutions by a factor of 2 to 500 , and these ratios increase with increasing distance away from the ridge axis. An evaluation of these results in the context of previous models of REE behavior indicates that. in fact, seawater experiences a net depletion in REEs as a result of hydrothermal activity. This is due primarily to the large scavenging capacity of iron oxyhydroxides which precipitate from these solutions. Such an interpretation explains why the REE content of seawater collected in the vicinity of hydrothermal vents is anomalously lower than "normal" seawater sampled from a comparable depth.
\end{abstract}

\section{INTRODUCTION}

THE CHEMICAL BUDGET of the rare earth elements (REEs) in the marine environment is not well understood because our knowledge of the significant sources and sinks of these elements is incomplete. Much of this uncertainty concerns the relationship between seafloor hydrothermal activity and the REE mass balance in the oceans. For example, PIPER (1974) suggested REE inputs from seafloor hydrothermal activity may be partially responsible for the observation that, in the pelagic Pacific Ocean, REEs are accumulating at a rate of 11 to 18 times greater than their supply from rivers. Specific questions regarding the role of hydrothermal processes in the marine REE budget have been stated succinctly by FLEET (1984): "Overall, does seawater gain or lose REEs while undergoing hydrothermal circulation at mid-ocean ridges and, if it does gain REEs, does the gain have a significant effect on the composition of seawater, or are the REEs lost at or near ridges by incorporation in metalliferous sediments?"

Recent investigations suggest the answers to these questions lie in an assessment of the net effect of two competing processes. Analyses of hydrothermal vent waters (MICHARD et al., 1983; MICHARD and ALBAREDE, 1986; HINKLEY and TATSUMOTO, 1987) indicate these solutions are enriched in REEs by a factor of 10 to nearly $10^{4}$ times that of ambient seawater. Too few analyses are now available to determine whether these REE levels are characteristic of "average" vent water; if they are, however, then hydrothermal REE inputs may represent a significant fraction of the total REE inputs to seawater. On the other hand, it is well documented that hydrothermal precipitates (especially Fe oxyhydroxides) that form in vent fluids can rapidly scavenge dissolved REEs (RuHLIN and OWEN, 1986a,b; OLIVAREZ and OWEN, 1987). Consequently, the enriched concentrations of REEs in vent

* Author to whom all correspondence should be addressed. fluids are not entirely transferred to seawater, but instead are diminished to some degree by the scavenging action of hydrothermal precipitates.

The present study examines these competing processes by developing a comparison between reported data on the REE chemistry of Pacific hydrothermal vent fluids and that of hydrothermal precipitates we have analyzed from the North and South Pacific Oceans. The net effect upon seawater is assessed by using the REE/Fe ratio of vent fluids and hydrothermal precipitates as an index of the fate of hydrothermal REE inputs.

\section{METHODS AND SAMPLE DESCRIPTION}

The sediment chemical data discussed in this report were obtained from the analysis of sediment cores collected from two areas of known seafloor hydrothermal activity. The first of these was recovered approximately $1150 \mathrm{~km}$ west of the axis of the East Pacific Rise (EPR), at Deep Sea Drilling Project (DSDP) Site $598\left(19^{\circ} 0.283 \mathrm{~S}\right.$, $124^{\circ} 40.606^{\prime} \mathrm{W}$ ). The 43 -meter column of sediments from this site represents a complete record of hydrothermal sedimentation along the western flank of the EPR during the past 16 million years and over paleodistances ranging from 9 to $1150 \mathrm{~km}$ from the ridge axis. A detailed description of the procedures used to analyze the 50 samples taken from this core, as well as the geochemical and mass accumulation rate data, is given in RUHLIN and OWEN $(1986 \mathrm{a}, \mathrm{b})$. The second core was obtained during a 1985 cruise of the R/VSurveyor as part of the National Oceanic and Atmospheric Administration's (NOAA) VENTS Program. This was an $80 \mathrm{~cm}$ Kasten core, designated KC1. recovered from a water depth of $2635 \mathrm{~m}$ approximately $15.6 \mathrm{~km}$ west $\left(44^{\circ} 44.21 \mathrm{~N}, 130^{\circ} 33.38 \mathrm{~W}\right)$ of the axis of the Southern Juan de Fuca Ridge (SJFR). The whole spreading rate in this area is $6 \mathrm{~cm} / \mathrm{yr}$ (ATWATER, 1970; ElVERS et al., 1974), and age dating of KC-l sediments yields a linear sedimentation rate of $0.61 \mathrm{~cm} / \mathrm{ky}$ (G. MAssoTH, pers. comm.). Assuming a constant linear sedimentation rate, we estimate the sediments in KC-1 include the upper $24 \%$ of the total sediment cover to basement and represent hydrothermal deposition during the past 130 thousand years over paleodistances ranging from approximately 12 to $16 \mathrm{~km}$ from the rise crest. A total of 20 samples collected at intervals of 1 to $5 \mathrm{~cm}$ were taken from this core, freezedried, and ground with mortar and pestle prior to analysis. Each sample was analyzed for the elements $\mathrm{Al}, \mathrm{Ba}, \mathrm{Co}, \mathrm{Fe}, \mathrm{Mg}, \mathrm{Mn}, \mathrm{Ni}$ $\mathrm{Si}, \mathrm{Ti}$, and the rare earth elements $\mathrm{La}, \mathrm{Ce}, \mathrm{Nd}, \mathrm{Sm}, \mathrm{Eu}, \mathrm{Tb}, \mathrm{Yb}$, and 
Lu by instrumental neutron activation analysis (INAA) at the Phoenix Memorial Laboratory. The University of Michigan, using standard INAA procedures (GORDON el al. 1968; DAMS and ROBBINS, 1970). Calcium carbonate content was measured using a conventional pressure bomb technique. Statistical analyses of the chemical data were performed using the Q-Mode factor analysis procedure of LIIINFN and Pisias (1984), kindly provided to us by these authors, and using MIDAS, a package of computer programs provided by the Statistical Research Laboratory at The University of Michigan (FOX and GUIRI: 1976).

\section{RESULTS AND DISCUSSION}

\section{Composition of the hydrothermal component}

Different approaches were required to characterize the composition of the hydrothermal component of the sediments at the two sampling locations. For Site 598, this process was straightforward because the sediments here are composed of a simple mixture of only two components: hydrothermal precipitates and biogenous carbonates (RUHLIN and OWFN, 1986a,b). Biogenous carbonates contain uniformly low concentrations of both Fe and the REEs (PALMER, 1985), and it can be assumed that the shell material acts as a simple diluent (i.e. it contributes negligibly to the total amount of $\mathrm{Fe}$ and REEs present, relative to the hydrothermal component). Consequently, the $\mathrm{Fe}$ and REE composition of the hydrothermal component of Site 598 sediments is represented by the bulk sediment concentrations of these elements corrected for the amount of carbonate material present (RUIILIN and OWEN, 1986a).

The sediments from SJFR are more complex because they contain detrital material in addition to biogenous and hydrothermal components. Because detrital material can contain significant amounts of both Fe and REEs, it was necessary to isolate and distinguish the composition of this phase relative to the hydrothermal materials present. The $Q$-mode factor analysis of LEINEN and PISIAS (1984), which is designed to identify the composition of geochemically significant endmembers in a bulk chemical data set, was used for this purpose. This analysis identified three compositional end-members (factors), which collectively account for $97 \%$ of the total variance in the chemical data set for the SJFR samples (Table 1).

Our interpretations of the geochemical significance of the three compositional end-members are as follows: Factor 1 = proximal hydrothermal component; Factor 2 = distal hydrothermal component; Factor 3 = detrital component. These interpretations were based on comparisons between key interelement ratios in each end-member and analogous ratios reported in the literature and considered to be characteristic for various marine sedimentary phases. For example, chemical fractionation of Fe from $\mathrm{Mn}$ occurs within a hydrothermal plume as it wafts from proximal to distal locations (MOTTL and MCCONACHY, 1989). This change should also be reflected in the composition of hydrothermal precipitates from the plume. The fractionation of $\mathrm{Fe}$ and $\mathrm{Mn}$ has been reported by MASSOTH et al. (1984) for surficial sediments along the SJFR and both Factors 1 and 2 exhibit properties consistent with an evolving plume. The $\mathrm{Mn} / \mathrm{Fe}$ ratio of Factor 1 is 0.07 , which is in agreement with values $(\mathrm{Mn} / \mathrm{Fe}=0.06$ $0.07)$ reported for proximal metalliferous sediments in the North and South Pacific (PIPER, et al. 1975; BONATTI and

\begin{tabular}{|c|c|c|c|}
\hline & Factor 1 & Factor 2 & Factor $3 \#$ \\
\hline $\begin{array}{l}\mathrm{Al} \% \\
\mathrm{Ba} \\
\mathrm{Co} \\
\mathrm{Fe} \% \\
\mathrm{Mg} \\
\mathrm{Mn} \\
\mathrm{Ni} \\
\mathrm{Si} \% \\
\mathrm{~T} \\
\mathrm{La} \\
\mathrm{Ce} \\
\mathrm{Nd} \\
\mathrm{Sm} \\
\mathrm{E} \mathrm{C} \\
\mathrm{Ib} \\
\mathrm{Yb} \\
\mathrm{Lu}\end{array}$ & $\begin{array}{l}4.82 \\
5210 \\
44.9 \\
6.30 \\
1020 \\
4580 \\
0.00 \\
24.0 \\
1960 \\
44.0 \\
48.4 \\
54.3 \\
8.41 \\
2.10 \\
2.32 \\
4.82 \\
1.41\end{array}$ & $\begin{array}{r}2.75 \\
8900 \\
101 \\
6.24 \\
3620 \\
27000 \\
245 \\
23.4 \\
220 \\
60.2 \\
32.3 \\
78.0 \\
10.1 \\
2.34 \\
0.00 \\
6.57 \\
1.28\end{array}$ & $\begin{array}{l}7.35 \\
5180 \\
25.1 \\
5.48 \\
7830 \\
4170 \\
13.9 \\
21.4 \\
4800 \\
23.9 \\
38.7 \\
56.6 \\
8.09 \\
1.93 \\
0.00 \\
4.28 \\
1.32 \\
\end{array}$ \\
\hline $\begin{array}{l}\% \text { Variance } \\
\% \text { Total } \\
\text { Variance }\end{array}$ & $\begin{array}{l}42 \\
42\end{array}$ & $\begin{array}{l}30 \\
72\end{array}$ & $\begin{array}{l}25 \\
97\end{array}$ \\
\hline
\end{tabular}

JOENSUU, 1966) and with hydrothermal plume particulates sampled in the proximal region ( $\sim 7 \mathrm{~km}$ from the axis) along the SJFR (G. MASSOTH, unpubl. data). The Mn/Fe ratio of Factor 2 is 0.43 , which is close to those values reported for "typical" hydrothermal sediments $(0.31-0.41)$ by GRAYBEAL and HF.ATH (1984). The value of this ratio also suggests that the sediments in core $\mathrm{KC}-1$ have not undergone a significant degree of diagenetic alteration. For example, the $\mathrm{Mn} / \mathrm{Fe}$ ratios for diagenetically altered ferromanganese deposits are usually much greater than 1.0 and typically range between 5 and 70 (BONATTI et al., 1972; DYMOND et al., 1984). Factor 3 is considered to represent a detrital component because several inter-element ratios (e.g. $\mathrm{Al} / \mathrm{Si}, \mathrm{Mg} / \mathrm{Al}, \mathrm{Co} / \mathrm{Al}$ ) fall within the range of values observed for lithogenous materials (GRAYBEAl. and HEATH, 1984; GROMET et al., 1984). (X-ray diffraction analyses of several samples from core $\mathrm{KC}-1$ confirmed the presence of detrital minerals, including quartz, K-feldspar, albite, and clay minerals.)

Other aspects of the SJFR data support the interpretations described above. For example, the relative amounts of each compositional end-member present in each SJFR sample were calculated using a linear programming normative analysis model. in which it was assumed that the bulk composition of each sample can be represented by some linear combination of each of the three end-members. The results of these calculations are shown as down-core profiles of each endmember in Fig. 1. The proximal hydrothermal factor systematically increases in total relative abundance downcore (i.e. towards the ridge axis), while the distal hydrothermal factor increases in total relative abundance towards the top of the core. No systematic change is observed for the detrital factor. BONA Trl (1981) has shown that ternary diagrams of $\mathrm{Fe}$ vs. Mn vs. $\mathrm{Co}+\mathrm{Ni}+\mathrm{Cu}$ can serve to distinguish hydrothermal and hydrogenous phases in ferromanganese deposits. Both the proximal and distal hydrothermal end-members interpreted here fall within the hydrothermal region of this type of plot (Fig. 2). Finally, we note that pure hydrothermal sed- 

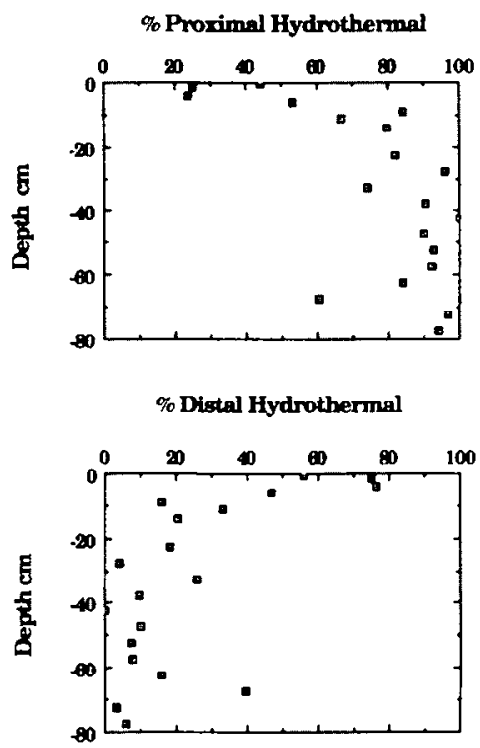

FIG. 1. Down-core profiles of the percentage fraction of each hydrothermal factor for SJFR core KC-1, reported on a detrital-free basis. Note that the proximal hydrothermal factor increases in abundance down-core (closer to the ridge axis) while the distal factor becomes more abundant at shallower depths.

iments have characteristic REE patterns which strongly resemble seawater patterns (BENDER et al., 1971; DYMOND et al., 1973). Previous studies have shown that the REE patterns of Site 598 (RUHLIN and OWEN, 1986a,b) and SJFR sediments (OLIVAREZ and OWEN, 1986) become more seawaterlike, and the Ce anomaly of Site 598 sediments approaches that of seawater with increasing distance from the rise crest (RUHLIN and OWEN, 1986a,b). The $\mathrm{Ce}$ anomaly $\left(\mathrm{Ce}^{*}\right)$ is defined as: $\mathrm{Ce}^{*}=\log (\mathrm{Ce} /(2 / 3 \mathrm{La}+1 / 3 \mathrm{Nd}))$, where $\mathrm{Ce}, \mathrm{La}$, and $\mathrm{Nd}$ refer to the shale-normalized values (ELDERFIELD and GREAVES, 1981); the $\mathrm{Ce}^{*}$ value for "average" seawater $=-0.78$. A linear regression of the $\mathrm{Ce}^{*}$ values for the SJFR sediments shows that they systematically decrease with increasing abundance of the distal hydrothermal factor and predicts a $\mathrm{Ce}^{*}$ value of -0.75 for a pure distal component, which is in good agreement with the "average" seawater value.

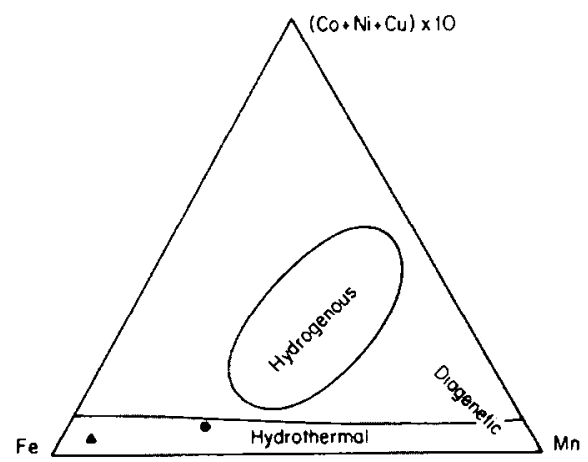

Fig. 2. Fe-Mn-(Co $+\mathrm{Ni}+\mathrm{Cu}$ ) ternary diagram (after Bonatri, 1981). The composition of both Factor I (proximal hydrothermal, $\Delta$ ) and Factor 2 (distal hydrothermal, $\bullet$ ) for KC-1 samples fall within the hydrothermal region. Cu values were estimated using known ratios of $\mathrm{Cu} / \mathrm{Ni}$ and $\mathrm{Cu} / \mathrm{Co}$ in hydrogenous phases (GRAYBEAL and HEATH, 1984)

\section{Fate of REE hydrothermal inputs}

Chemical analyses of seafloor hydrothermal vent fluids (HINKLEY and TATSUMOTO, 1987; MiChARD and ALBAREDE, 1986; MichaRD et al., 1983, 1984; PHILPOTTS et al.. 1987; VON DAMM and BISCHOFF, 1987) have consistently shown that these solutions are significantly enriched in REEs and Fe relative to ambient seawater. However, the vent-derived REEs are susceptible to removal from solution through the scavenging action of particulate matter, especially Fe oxyhydroxides (RUHLIN and OWEN, 1986a; OLIVAREZ and OWEN, 1987), which rapidly precipitate from the same vent fluids. The question of whether or not REEs in vent waters represent a true input to seawater thus depends upon the extent to which they can "escape" this scavenging process. In order to assess the fate of REEs derived from vent fluids, we have developed a comparison between the REE/Fe ratios which are displayed by hydrothermal fluids $v s$. analogous ratios determined for hydrothermal sediments (Table 2). Vent fluid data were obtained from the literature, whereas the REE/ Fe values for hydrothermal sediments were taken from the results of the end-member factor analysis (Table 1; SJFR) and from RUILIN and OWEN (1986a, Site 598). For Site 598, the proximal end-member ratios represent the $y$-intercept $(0$ $\mathrm{km}$ ) values derived from the linear regression analyses of the $\mathrm{REE} / \mathrm{Fe}$ concentration data $v s$. the distance of deposition from the paleo-rise crest. This regression was performed for each of the eight REEs and is based on 34 samples which span a deposition range between $9 \mathrm{~km}$ and $474 \mathrm{~km}$ from the paleorise crest. In all cases the $y$-intercept value representing the proximal ratio is significant at the 0.01 level. The distal endmember values reported for Site 598 are from sediments deposited $802 \mathrm{~km}$ from the paleo-rise crest (RUHLIN and OWEN, 1986a, Table 2).

There are three possible outcomes to any comparison of REE/Fe ratios in vent fluids versus hydrothermal sediments. These outcomes, along with our interpretation of each, are summarized in the following cases:

Table 2. REE/Fe ratio $\left(\times 10^{6}\right)$ in Pacific hydrothermal phases.

\begin{tabular}{|c|c|c|c|c|c|c|c|}
\hline & \multicolumn{3}{|c|}{ Solutions § } & \multicolumn{4}{|c|}{ Sediments } \\
\hline \multirow{2}{*}{$\begin{array}{l}\text { Site: } \\
\text { Dist." }\end{array}$} & \multicolumn{2}{|c|}{$\begin{array}{c}\text { EPR } \\
13 N \quad 21 N\end{array}$} & \multirow[t]{2}{*}{ SJFR } & \multicolumn{2}{|c|}{$\begin{array}{c}\text { EPR } \\
\text { Site } 598\end{array}$} & \multicolumn{2}{|c|}{$\begin{array}{r}\text { SJFR } \\
\text { KC-1 }\end{array}$} \\
\hline & & & & $\begin{array}{c}\text { Prox. } \\
0\end{array}$ & $\begin{array}{l}\text { Distal } \\
802\end{array}$ & $\begin{array}{l}\text { Prox. } \\
\text { s10 }\end{array}$ & $\begin{array}{c}\text { Distal } \\
\geq 16\end{array}$ \\
\hline $\mathrm{La} / \mathrm{Fe}$ & ... & $\ldots$ & $\ldots$ & 270 & 1200 & 700 & 960 \\
\hline $\mathrm{Ce} / \mathrm{Fe}$ & 24.0 & 13.3 & ... & 33 & 218 & 760 & 510 \\
\hline $\mathrm{Nd} / \mathrm{Fe}$ & 14.0 & 3.33 & 2.99 & 180 & 991 & 800 & 1200 \\
\hline $\mathrm{Sm} / \mathrm{Fe}$ & 6.0 & 0.910 & 0.63 & 41 & 203 & 130 & 162 \\
\hline $\mathrm{Eu} / \mathrm{Fe}$ & 9.9 & 2.02 & $\ldots$ & 11 & 56 & 33 & 37 \\
\hline Tb/Fe & $\ldots$ & -... & -.- & 54 & 35 & 36 & $\ldots$ \\
\hline $\mathrm{Yb} / \mathrm{Fe}$ & 0.59 & 0.29 & $\ldots$ & 22 & 132 & 76 & 100 \\
\hline $\mathrm{Lu} / \mathrm{Fe}$ & ... & $\ldots$ & ... & 5 & $\mathbf{2 8}$ & 2 & 21 \\
\hline
\end{tabular}

$\$$ Data sources:

REE's: EPR: Michard and Albarede (1986); avg. of samples 14 Ti2 \& $14 T$ T4 (13 N), HG \& OBS (21 N). SJFR: Hinkley and Tatsumoto (1987). Fe: $13 \mathrm{~N}$ : Michard et al. (1984); 21 N Von Damm et al. (1985); SJFR: Philpotts et al. (1987).

* Site 598 data from Ruhlin and Owen (1986a, Table 2). Prox values obtained by linear regression of $\mathrm{REE} / \mathrm{Fe}$ conc. ratio vs. distance from paleo-rise crest to $0 \mathrm{~km}$. $(n=34$, above lysocline samples). SJFR date from Table 1, this text.

\# Orthogonal distance $(\mathrm{km})$ from axis of paieo-rise crest. 
Case $1:$ Vent fluid ratio $=$ sediment ratio. This suggests there is a quantitative removal of vent-derived REEs by hydrothermal precipitates; i.e., REEs from hydrothermal sources have no net effect upon the composition of seawater.

Case 2: Vent fluid ratio $>$ sediment ratio. This result implies that some portion of the vent-derived REEs escaped the scavenging process and thus represent a net input to seawater.

Case 3: Vent fluid ratio < sediment ratio. This outcome suggests that the scavenging capacity of hydrothermal precipitates is sufficiently large to incorporate all vent-derived REEs as well as additional REEs from the ambient seawater that mixes with the vent fluids.

All comparisons (Fig. 3a,b) of the REE/Fe ratio of vent fluids vs. hydrothermal sediments at both sampling sites are consistent with Case 3 ; i.e., the influx of hydrothermal fluids results in a net removal of REEs from seawater. Moreover. all but one of these comparisons exhibit the following trend for the REE/Fe ratios: vent fluids < proximal sediments $<$ distal sediments, which suggests a continuous uptake of REEs away from the ridge axis. The distance which separates the proximal and distal hydrothermal sediments at SJFR is on the order of $\sim 4 \mathrm{~km}$, while at Site 598 this distance $(802$ $\mathrm{km}$ ) is more than two orders of magnitude greater. Inasmuch as they have travelled a greater distance from the injection site, distal hydrothermal sediments at Site 598 have also been exposed to seawater longer than distal sediments at SJFR. Note that the percent increase in the REE/Fe ratio between proximal and distal components is greater at Site 598 relative to SJFR (Table 2). We believe that continuous REE scavenging over a greater distance accounts for the differences observed between these two sites.

\section{(a) EPR (Site 598)}
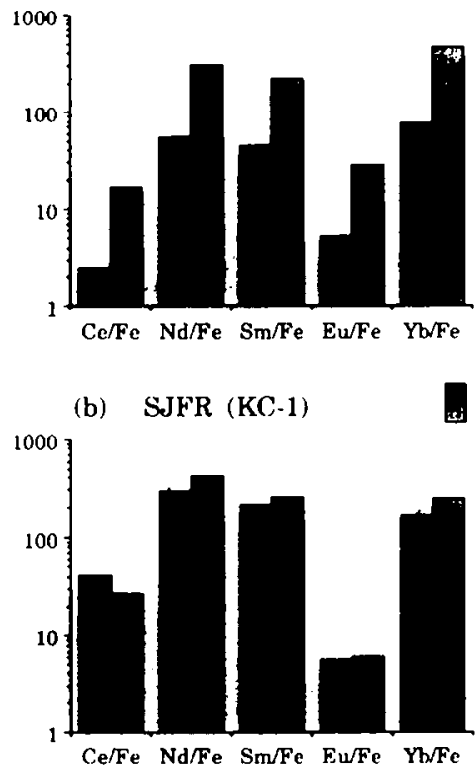

FIc. 3. Bar graph of the ratio of REE/Fe values in hydrothermal sediments from (a) Site 598, EPR at $19^{\circ}$ S, and (b) Core KC-1, SJFR, divided by the REE/Fe value in hydrothermal plumes (Table 2 ). For nearly all cases the ratios are much greater than one (implying a net REE removal from seawater), and distal ratios are generally greater than proximal ratios (implying continuous REE scavenging by distal hydrothermal precipitates).
The fact that the sediment $\mathrm{REE} / \mathrm{Fe}$ ratio for the proximal factor is significantly greater than the vent fluid ratio suggests that removal of REEs from the plume is both rapid and extensive. Rapid removal is evident in analyses of nearly pure vent fluids from the SJFR which indicate that both Fe and the REEs behave nonconservatively upon mixing with seawater (Hinkley and TATSUMoto, 1987; Philpotts el al., 1987); i.e., their concentrations are markedly less than what would be expected based upon simple mixing between the hydrothermal fluid and seawater end-members. DYMOND (1981) has shown that hydrothermal precipitates, most likely transported as colloidal-sized particles, are dispersed thousands of kilometers away from the vent site. These particles apparently continue to scavenge REEs during transport, as indicated by measurements of REEs in seawater collected down-plume from active hydrothermal vent fields (KLINKHAMMER et al., 1983). These samples are depleted in REEs relative to normal seawater at a comparable depth (Table 3 ).

Analyses of vent fluids at $13^{\circ} \mathrm{N}, 21^{\circ} \mathrm{N}$ and along the SJFR indicate $\mathrm{Fe}$ is enriched $10^{6}$ to $10^{7}$ times its average seawater concentration (MICHARD et al., 1984; VON DAMM et al., 1985; PHILPOTrs et al., 1987), while the corresponding REE enrichments in these fluids (MICHARD and ALBAREDE, 1986; HINKLEY and TATSUMOTO, 1987) are in the range of 10 to $10^{4}$. Assuming these data are representative, we conclude the fate of hydrothermal REE inputs is determined by the overwhelming amount of $\mathrm{Fe}$ in vent fluids and that the scavenging capacity of the Fe-rich hydrothermal precipitates is sufficient to remove additional REEs from the ambient seawater that mixes with the plume. As a first approximation, our calculations assume that all hydrothermal $\mathrm{Fe}$ inputs will precipitate as oxides/hydroxides upon mixing with seawater and thus be in a form capable of scavenging REEs. We recognize that this assumption is not always valid; however, MOTTL and MCCONACHY (1989) have studied the evolution of hydrothermal solutions near $21^{\circ} \mathrm{N}$ and concluded that $50 \pm 30 \%$ of the $\mathrm{Fe}$ will precipitate as oxides even in the presence of excess $\mathrm{H}_{2} \mathrm{~S}$. Taking these results into account, our estimates of the $\mathrm{REE} / \mathrm{Fe}$ ratios for hydrothermal plumes may be too low by a factor of 1.25 to 5.0. This consideration would have no effect on the sense of our results in the average case (only $50 \%$ of the hydrothermal Fe precipitates as oxides): hydrothermal Fe-oxide precipitates would still produce a net removal of REEs from seawater. In the extreme case (only $20 \%$ of the hydrothermal Fe precipitates as oxides) some ventderived $\mathrm{Ce}$ and $\mathrm{Eu}$ would initially be added to seawater, but these additions would either be roughly balanced (for Eu) or more than offset (for $\mathrm{Ce}$ ) by the scavenging action of distal hydrothermal precipitates. Furthermore, in each of these cases it is likely that REE removal from seawater would be augmented by scavenging by other solid phases, such as Mn oxyhydroxides (e.g. KLINKHAMMER et al., 1983).

\section{SUMMARY AND CONCLUSIONS}

The role that seafloor hydrothermal activity plays in determining the REE composition of seawater depends upon the interplay between two competing processes. Seawaterbasalt reactions during hydrothermal circulation produce significant enrichments, relative to normal seawater concentrations, of both Fe and REEs in hydrothermal vent fluids. 
Table 3. Actual and normalized REE concentrations $(\mathrm{ng} / \mathrm{kg}$ ) from seawater near hydrothermal vents.

\begin{tabular}{cccc}
\hline & $\begin{array}{c}\text { NW Pacific } \\
(2500 \mathrm{~m})\end{array}$ & $\begin{array}{c}\text { SE Pacific } \\
(2500 \mathrm{~m})\end{array}$ & $\begin{array}{c}\text { Normalized } \\
\text { Concencration * }\end{array}$ \\
\hline $\mathrm{La}$ & 6.5 & 4.2 & 0.61 \\
$\mathrm{Ce}$ & 1.3 & 0.49 & 2.2 \\
$\mathrm{Nd}$ & 4.3 & 2.3 & 0.53 \\
$\mathrm{Sm}$ & 0.80 & 0.41 & 0.43 \\
$\mathrm{Eu}$ & 0.21 & 0.12 & 0.47 \\
$\mathrm{Gd}$ & 1.3 & 0.79 & 0.52 \\
$\mathrm{Yb}$ & 1.4 & 1.3 & 0.46 \\
\hline * From Klinkhammer et al. (1983); NW Pacific \\
= Mariana Trough; SE Pacific = EPR at 19S. \\
* Average value for both sites divided by \\
seawaver concentration (de Baar et al., 1985) \\
at 2750 meters (after Owen and Olivarez, 1988).
\end{tabular}

Upon discharge into oxidized bottom waters, however, the dissolved $\mathrm{Fe}$ is rapidly precipitated as iron oxyhydroxides which, in turn, can serve as highly efficient scavengers of REEs. Thus, for seafloor hydrothermal activity to represent a source of REEs to seawater requires that some portion of the hydrothermal REE inputs escape this scavenging process. Our comparison of the REE/Fe ratios measured in hydrothermal vent fluids vs. those determined for proximal and distal hydrothermal sediments at two Pacific sites indicates the scavenging capacity of hydrothermal precipitates is not only sufficient to incorporate all vent-derived REEs but also causes significant REE removal from the ambient seawater that mixes with the vent fluids.

This finding may in part explain certain puzzling observations concerning the marine geochemistry of the REEs. For example, PIPER (1974) identified an imbalance in the REE budget of Pacific pelagic sediments in which REE removal rates were several times greater than their river input rates. Although active seafloor venting had not yet been discovered, he suggested that the input and subsequent removal of REEs from hydrothermal sources might account for this discrepancy. Subsequent documentation of REE enrichments in vent fluids, along with evidence presented here of both a rapid removal of vent-derived REE inputs by hydrothermal precipitates and of their augmentation with REEs from surrounding seawater, is consistent with this explanation. A more recent problem is that, contrary to expectations based upon documented REE enrichments in vent fluids, REE concentrations in seawter collected near hydrothermal vents (KLINKHAMMER et al., 1983) are depleted relative to normal seawater at a comparable depth (OWEN and OLIVAREZ, 1988). Our results suggest that this anomaly is the result of intense REE scavenging by hydrothermal precipitates derived from the nearby vents.

Acknowledgements-The sediment samples used in this study were obtained during the 1983 cruise of the Glomar Challenger, sponsored by the Deep Sea Drilling Project of the National Science Foundation, and during a 1985 cruise of the Surveyor, sponsored by the VENTS program of the National Oceanic and Atmospheric Administration. We thank the crew members of these vessels and our colleagues who were members of the scientific parties on these cruises for their invaluable assistance in obtaining these samples. This research was supported in part by the National Science Foundation under Grant No. OCE-8410034, the U.S. Bureau of Mines under Grant No. G1185128 (MMTC-89-3), and the Michigan Sea Grant College Program under Grant Nos. NA85A-D-SG045 and NA86AA-D-SG043. We are grateful to G. Faure, M. Lyle, L. Walter and an anonymous reviewer for comments and sugsestions they offered based on a review of an earlier version of this paper.

Editorial handling: G. Faure

\section{REFERENCES}

ATWATER T. (1970) Implications of plate tectonics for the Cenozoic tectonic evolution of western North America. Geol. Soc. Amer. Bull. 81, 3513-3536.

BENDER M., BRoecker W., GoRNitz V., MidDEl U., KAY R., SUN S. S. and BISCAYE P. (1971) Geochemistry of three cores from the East Pacific Rise. Earth Planet. Sci. Lett. 12, 425-433.

BONATTI E. (1981) Metal deposits in the oceanic lithosphere. In The Sea (ed. C. EMILIANI), Vol. 7, pp. 639-686. J. Wiley \& Sons.

BONATTI E. and JoEnsuU O. (1966) Deep-sea iron deposit from the South Pacific. Science 154, 643-645.

BONATTI, E., KRAEMER T. and RYDELl H. (1972) Classification and genesis of submarine iron-manganese deposits. In Papers from a Conference on Ferromanganese Deposits on the Ocean Floor (ed. D. HORN), pp. 149-166. National Science Foundation, Washington, D.C.

DAMS R. and RoBBINS V. A. (1970) Nondestructive activation analysis of environmental samples. The Univ, of Michigan, Great Lakes Res. Div., Tech. Rept. No. 48, Ann Arbor, Michigan.

Debaar H. J., Bacon M. P., Brewer P. G. and Bruland K. W. (1985) Rare earth elements in Pacific and Atlantic Oceans. Geochim. Cosmochim. Acta 49, 1943-1959.

DYMOND J. (1981) Geochemistry of Nazca plate surface sediments: An evaluation of hydrothermal, biogenic, detrital, and hydrogenous sources. Geol. Soc. Amer. Mem. 154 (eds. L. D. KULM, J. DYMOND, E. J. DASCH, D. M. HuSSONG), pp. 133-174.

DYmond J., Corliss J. B., Heath G. R., Field C. W., Dasch E. J. and VEEH H. H. (1973) Origin of metalliferous sediments from the Pacific Ocean. Geol. Soc. Amer. Bull. 84, 3355-3372.

Dymond J., Lyle M., Finney B., Piper D., Murphy K., Conard R. and PISIAS N. (1984) Ferromanganese nodules from MANOP Sites H, S, and R-Control of mineralogical and chemical composition by multiple accretionary processes. Geochim. Cosmochim. Acta 48, 931-950.

Elderfield H. and Greaves M. J. (1981) Negative cerium anomalies in the rare earth element patterns of oceanic ferromanganese nodules. Earth Planet. Sci. Lett. 55, 163-170.

Elvers D.. POTTER K., Seidel. D., and MORLEy J. (1974) Survey or seamap N.O.S. seamap profiles plates BGM-1-71, NOAA Environ. Data Serv.

FLEET A. J. (1984) Aqueous and sedimentary genchemisry of the rare earth elements. In Rare Earth Element Geochemistry (ed. P. HENDERSON), pp. 343-373, Elsevier.

Fox D. J. and GUIRE K. E. (1976) Documentation for MIDAS, 3rd edn. The Statistical Research Laboratory. The University of Michigan, Ann Arbor.

Gordon C. E., Randle K., Goles G. D., Corliss J. B., Beesen M. H. and OXLEY S. S. (1968) Instrumental activation analysis of standard rocks with high resolution X-ray detectors. Geochim. Cosmochim. Acta 32, 364-396.

Graybeal A. L. and HeATH G. R. (1984) Remobilization of transition metals in surficial pelagic sediments from the Eastern Pacific. Geochim. Cosmochim. Acta 48, 965-976.

Gromet L. P., DYmek R. F., Haskin L. A. and Korotev R. L. (1984) The "North American shale composite": Its compilation, major and trace element characteristics. Geochim. Cosmochim. Acta 48, 2469-2482.

HiNKLEY T. K. and TATSUMOTO M. (1987) Metals and isotopes in Juan de Fuca Ridge hydrothermal fluids and their associated solid materials. J. Geophys. Res. 92, 1943-1959.

Klinkhammer G., Elderfield H., and Hudson A. (1983) Rare earth elements in seawater near hydrothermal vents. Nature (London), 305, 185-188.

LEINEN M. and PISIAS N. (1984) An objective technique for determining end-member compositions and for partitioning sediments according to their sources. Geochim. Cosmochim. Acta 48, 47-62. Massoth G. J., Baker E. T., Feely R. A. and Curl H. C. JR. 
(1984) Hydrothermal signals away from the southern Juan de Fuca Ridge (abstr.). Eos 65, 1112.

MICHARD A. and ALBAREDE F. (1986) The REE content of some hydrothermal fluids. Chem. Geol. 55, 51-60.

Michard A., Albarede. F., Michard G., Minster J. F., and Charlou J. L. (1983) Rare earth elements and uranium in hightemperature solutions from East Pacific Rise hydrothermal vent field $\left(13^{\circ} \mathrm{N}\right)$. Nature (London) 303, 795-797.

Michard G., Albarede F., Michard a., Minster J.-F., Chari.ol: J. L., and TAN N. (1984) Chemistry of solutions from the $13^{\circ} \mathrm{N}$ East Pacific Rise hydrothermal site. Earth Planet. Sci. Lett. 67, 297-307.

MOTTL M. J. and MCCONaChy T. F. (1989) Chemical processes in buoyant hydrothermal plumes on the East Pacific Rise near $21^{\circ} \mathrm{N}$. Geochim. Cosmochim. Acta (submitted)

Ol.JvARt $\angle$ A. M. and OWEN R. M. (1986) Geochemical associations of the rare earth elements in a shallow core from the Juan de Fuca Ridge (abstr.). Eos 67, 1027.

OLIVAREZ A. M. and OWEN R. M. (1987) Scavenging and mass accumulation of REE in Pacific hydrothermal precipitates (abstr.). EOS 68, 1326.

OWE.N R. M. and OlivaREZ A. M. (1988) Geochemistry of rare earth elements in Pacific hydrothermal sediments. Mar. Chem. 25, 183196.

PALMFR M. R. (1985) Rare earth elements in foraminifera tests. Earth Planet. Sci. Lett. 73, 285-298.
Phil.potts J. A., ARusc avage P. J. and Von Damm K. L. (1987) Uniformity and diversity in the composition of mineralizing fluids from hydrothermal vents on the Southern Juan de Fuca Ridge. J. (jeophys. Res. 92, 11327-11333.

PIPFR D. Z. (1974) Rare earth elements in the sedimentary cycle: A summary. Chem. Geol 14, 285-304

Piper D. Z., VFen H. H., Bertrand W. G., and Chase R. L. (1975) An iron-rich deposit from the Northeast Pacific. Earth Planet. Sci. Lett. 26, 114-120.

Riunlis D. E. and Owtis R. M. (1986a) The rare earth element geochemistry of hydrothermal sediments from the East Pacific Rise: Examination of a seawater scavenging mechanism. Geochim. Cosmochim. Acta 50, 393-400.

RUHLIN D. E. and OWEN R. M. (1986b) Factors influencing the rare earth element composition of hydrothermal precipitates, East Pacific Rise. In Init. Repts. DSDP (eds. M. LEINEN and D. K. REA), Vol. XCII. pp. 383-389. U.S. Govt. Printing Office, Washington. D.C.

VON DAMM K. L. and BISCHOFF J. L. (1987) Chemistry of hydrothermal solutions from the Southern Juan de Fuca Ridge. J. Geophys. Res. 92, B11:11334-11346.

Von damm K. L., Edmond J. M., Grant B., Measures C. I., WALDEN B.. and WEISS R. F. (1985) Chemistry of submarine hydrothermal solutions at $21^{\circ} \mathrm{N}$. East Pacific Rise. Geochim. Cosmochim. Acla 49, 2197-2200. 